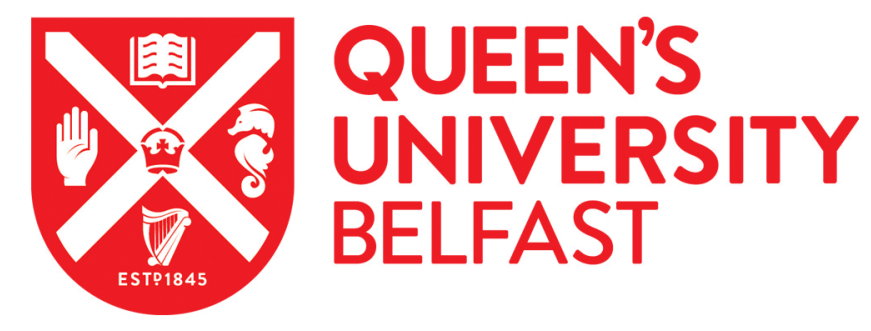

\title{
Getting Close to the Action: The Micro-Politics of Rural Development
}

McAreavey, R. (2006). Getting Close to the Action: The Micro-Politics of Rural Development. Sociologia Ruralis, 46(2), 85-103. https://doi.org/10.1111/j.1467-9523.2006.00407.x

\author{
Published in: \\ Sociologia Ruralis
}

Document Version:

Peer reviewed version

Queen's University Belfast - Research Portal:

Link to publication record in Queen's University Belfast Research Portal

\section{Publisher rights}

( 2006 The Author. Journal Compilation @ 2006 European Society for Rural Sociology

This is the peer reviewed version of the following article: McAreavey, R. (2006), Getting Close to the Action: The Micro-Politics of Rural Development. Sociologia Ruralis, 46: 85-103., which has been published in final form at http://onlinelibrary.wiley.com/doi/10.1111/j.14679523.2006.00407.x/abstract. This article may be used for non-commercial purposes in accordance with Wiley Terms and Conditions for SelfArchiving

\section{General rights}

Copyright for the publications made accessible via the Queen's University Belfast Research Portal is retained by the author(s) and / or other copyright owners and it is a condition of accessing these publications that users recognise and abide by the legal requirements associated with these rights.

\section{Take down policy}

The Research Portal is Queen's institutional repository that provides access to Queen's research output. Every effort has been made to ensure that content in the Research Portal does not infringe any person's rights, or applicable UK laws. If you discover content in the Research Portal that you believe breaches copyright or violates any law, please contact openaccess@qub.ac.uk. 


\title{
Getting close to the action: the micro-politics of rural development
}

\author{
Dr. Ruth McAreavey \\ Research Manager \\ Gibson Institute for Land, Food and the Environment \\ Queen's University Belfast
}

\section{Introduction}

One of the difficulties with exploring and analysing micro-politics lies in their very elusiveness. Rural development/regeneration literature typically implies the importance of micro-politics with little outright or explicit reference to the significance of these intangibles and subtleties. Listening in to any casual conversation in the regeneration sector demonstrates that people on the ground understand the role of micro-politics. For instance, the practitioner will grasp the importance of holding a meeting in what is perceived to be a neutral venue, or in any case rotating the venue to avoid a particular interest group dominating the process. Equally those directly involved in the group appreciate the need to spend time clarifying objectives, even though such time spent does not always contribute to the achievement of goals in an obvious or direct way. Few involved in rural development would argue against the importance of having effective meetings, positive consultation or useful participation. While practitioners acknowledge the significance of micro-politics, it remains a relatively under-theorised concept in academic literature. There are some recent and useful exceptions. Barnes et al highlight the relevance of 'micro processes' (2003, p.397) in constructing notions of representation and legitimate participation, calling for analysis of 'micro-politics' of interactions rather than sweeping statements (2003, pp.396/7); Murtagh (2001) and Scott (2004) each investigate micro-processes within partnership structures. Nonetheless there is little known about how micro-politics emerge in rural development practice, why they vary so much between groups and why it play such a crucial role in rural development practice. This may be in part due to the very elusive and intangible nature of micro-politics which in turn militates against distinguishing and subsequently analysing the concept. A group of people come together to achieve specific things, but what actually happens? How do 
they go about running their meetings? How do people interact? Given similar funding and development opportunities what is it that makes one process more effective than another? An analysis of the micro-politics of rural development practice provides important insights into these questions.

Identification and analysis of micro-political processes therefore contribute to rural development theory and practice in a number of ways. Forming part of the theoretical underpinning of social capital this research serves to advance the social capital debate and thereby also overcomes a criticism directed at rural research of failing to engage with, and develop, theoretical concepts (Woods and Goodwin, 2003). In addition examination of micro-politics contributes to a better understanding of the mechanisms and processes of rural governance as it facilitates better knowledge of the practices associated with rural governance at the individual and group level. This is an underresearched area with much previous and emerging research considering relations between the state and structures of rural governance, typically that of rural partnerships (see for example Thompson, 2005; Edwards et al, 2001; Mackinnon, 2002); fewer studies consider the relations that emerge at an operational level between rural development actors. Even those analyses that do examine relations between actors suggest that further knowledge of these relations would contribute to our understanding of the structures and processes of rural governance (Shortall, 2004; Hayward, Simpson and Wood, 2004; Storey, 1999 and Edwards, 1998). Given the rise in popularity of the partnership in rural governance in Europe and beyond (Shortall, 2004; Goodwin, 2003 and Cheverett, 1999), and the accompanying implicit reliance on positive group interaction, illumination of micro-politics can only serve to increase our understanding of what constitutes effective rural development practice. Thus whilst the empirical research informing this article was based in the UK, the findings will have wider resonance.

There is a general belief that people form voluntary alliances because they have a common interest; this is often to exert pressure and to make change (Croft and Beresford, 1992). Individuals get involved with rural development because they believe they have a valid contribution to make to a particular situation as well as a benefit to be gained. 
Their contributions are all encompassing and range from having specific technical skills that are relevant to the group, to broader support including time and willingness to attend meetings. There are many different intangible benefits of participatory initiatives such as the development of leadership or public speaking skills and the acquisition of new information or networks by community members (Hayward, Simpson and Wood, 2004). These complement the outputs that are typically required by rural development programmes such as improved community facilities or the employment of personnel. Common to all rural development activity is interaction with other people due to some shared interest.

Micro-politics are intangible aspects that arise due to such groups of individuals interacting and working together on shared activity; they relate to processes that occur within a group. Relating to both positive and negative aspects of rural development group dynamics, micro-politics encompass trust, norms, shared knowledge, perceptions, understanding, social networks, values and personality traits. Inappropriate meeting behaviour, meetings outside meetings, bad mouthing the group and snide remarks further symbolise negative micro-politics. New friendships, new groups, the 'feel good' factor and positive social interaction are more positive aspects of micro-politics. In short both positive and negative aspects relate to what happens in the process of achieving broader rural development (social, economic or environmental) goals as opposed to the ultimate objective. As both positive and negative impacts result from micro-politics, they are different from, although related to, social capital; a theme which is discussed later in the article.

Relating to the factors that are not instantly observable - the surface must be scratched and investigated to reveal micro-politics at play. These are similar to the 'structures and processes beyond what is immediately perceivable' as described by McDowell (1992, p.213) on the subject of elite interviewing. They help to make the story behind every good or bad project. This story is not necessarily the one that funders or other officials hear or wish to hear about, but is often more revealing than an annual report or list of achievements. Micro-politics are the intangibles for which traditionally there is no direct 
financial support. That stated, funding may not be given unless a community has demonstrated that it has paid attention to some process issues as was the case with participation in the Single Regeneration Budget (Department of Environment, Transport and the Regions, 1999). From such processes, micro-politics emerge.

Getting a grasp on rural development group minutiae that constitute micro-politics can be difficult as the emphasis is typically placed on 'bigger' issues. For instance rural development is presented for 'the community' and emphasis is placed on the ideology behind the community coming together. But as Taylor (2003) argues, the rules of the game require a steep learning curve and heavy workload which rules many people out. Consequently regeneration projects latch onto 'stars' (Taylor, 2003, p.194) and so the reality tends to involve a few key individuals who take on the role of volunteer or champion within their community. Taylor's research showed that people from the voluntary and community sector 'felt that now the real decisions were made elsewhere and that they were involved in the micropolitics' (2003, p.191) as they were working within rules that already determine how things will happen. Pre-occupation by particular groups with such micro-politics could mean loss of focus on other core concerns and objectives.

Micro-politics relate to processes and norms within a rural development group. They encompass the intangible components that are necessary for a group to function effectively, but also those issues that can result in ineffective and inefficient activity. Micro-political processes refer to the factors underpinning group relations and thus have both positive and negative qualities. Micro-politics depict knowledge, power, trust, perceptions, understanding, social networks, values and traits that arise as a result of individuals interacting within a group whilst working on a shared ideological goal, such as rural development.

The remainder of this article considers the significance of micro-politics in the context of rural development. Firstly a literature review is presented which distinguishes micropolitics from social capital. It then analyses the key elements that impact on group 
processes including trust, power and relations within the group and norms that emerge at meetings. Next the research is described. Following a presentation of the research findings, the discussion and conclusion consider how to manage micro-politics within rural regeneration.

\section{Overview of the literature}

Micro-politics are about group relations and the associated norms. They relate to shared knowledge, perceptions, understanding, social networks, values and traits that exist within a rural development group. In some of the literature these nebulous concepts have been aligned to and described as social capital (see for instance Dhesi, 2000) and thus micro-political processes underpin the formation of social capital. Nonetheless micropolitics are distinguished from the broader 'social capital' label in this article for several reasons including the confusion around its meaning; the emphasis of social capital on the positive outcomes; and the desire to unpick these subtle processes.

\section{Micro-politics, not social capital}

Social capital as a concept has found popularity among many academics and policymakers alike at a European and an international level. See for instance Putnam (1993), Falk and Kilpatrick (2000), Portes (2000), Shucksmith (2000) and Svendsen and Svendsen (2000). Complete books have analysed its application across the disciplines (see for instance Baron, Field and Schuller, 2000) and Bill Clinton found inspiration in it for his State of the Union address in 1995 (Portes, 1998). Many definitions and meanings are offered within this literature. Consequently social capital has 'become a hot topic among social scientists of late....the term has been used so often to mean so many different things that it has become the equivalent of an empty container, readily filled with whatever meaning the user- or the listener or reader- brings to the conversation' (Servon, 2003, p.13).

Secondly, and as Portes (1998) points out, literature on social capital tends to focus on the positive consequences. Indeed the manner in which social capital is used implicates it as a panacea for many of the difficulties facing communities (see for instance Putnam, 
1993) and this in turn has caused debate on whether social capital is a cure-all for modern society's ailments (Maloney, Smith and Stoker 2000, Body-Gendrot and Gittel, 2003). Focusing only on the positive aspect of social capital ignores negative outcomes such as the exclusion of outsiders and excess claims on group members (Shortall, 2004 and Portes, 1998). Consequently Portes (2000) and Bridger and Luloff (2001) conclude that more work needs to be done before social capital is adopted as reliable public policy.

While this paper does not enter a more detailed debate on social capital, it is recognised that micro-politics and social capital are closely linked. Micro-political processes underpin social capital and indeed have commonalties with the characteristics of social capital. Consequently, some aspects of micro-politics contribute to the issues that are the focus of social capital debates. The following discussion examines some of these concepts, namely trust and power. This study is not an analysis of social capital per se; however, given the relationship between social capital and micro-political processes, it does offer insight into the social capital approach. It is a study of the role and importance of micro-politics to rural development theory and practice. Micro-politics are broadly defined as the intangibles occurring within a group as a result of the interaction of a set of individuals working together.

\section{The minutiae of micro-politics}

While discussing planning issues Lowry, Adler and Milner voice concern about the way that group processes are 'sometimes designed and conducted in ways that - intentionally and unintentionally - limit participation and manipulate consent.' (1997, p.178). They go on to call for greater attention to explicit and implicit group processes to help guide those working in the planning field. The same is true for the rural development sector sensitivity to group procedures, including covert and overt practices, is essential. Implicit processes are allied to group relations and encompass trust, power and legitimacy. From these emerge overt practices including group norms such as the pattern of group meetings or the process of decision making, all of which influence a group's effectiveness. A theoretical context to these group processes is provided in this section. 
The rural development group evolves to exhibit a rhythm of norms that provide familiarity to members. The process of making a decision or the format for a meeting represents some of the characteristics that emerge as standard group features. Arnstein (1969) analysed in detail the relationship between citizen power and decision-making demonstrating its complexity with circumstances ranging from manipulation to control. Groups handle general discussion and decision making in a different way - some strive for consensus on everything while others are content with majority rule. The favoured decision making method is likely to be put to the test sooner or later especially where there is conflict and potential for differing interests. Lowry, Adler and Milner point out 'too much emphasis on decision making can cause us to miss the subtler ways in which power is used in participation' (1997, p.182). Power can be brandished through manipulation of the agenda, but this is not always shown in an obvious way. Individuals may exert power in a covert manner by influencing issues that do and do not get discussed within meetings, demonstrating a hidden dimension of power (Lukes, 1974). Decision making intricacies are thus about more than who is actually in control of decision making and how decisions are made. Crucially they are also about what decisions are made, or not, by a group. Such complexities are influenced by group interactions and relations which are dependent on the existence of trust, power and legitimacy resulting in the emergence of micro-politics.

Trust not only exists through group interaction, but Bloomfield et al (2002) state that it is still most easily engendered by regular face-to-face discussions over an extended period. Trust itself is crucial as it is often seen as the starting point of voluntary association and Putnam (1993) argues that along with involvement and co-operation it is also an essential ingredient of networks of affiliation which in turn form crucial ingredients of society. Trust refers 'to ethical relations which are not conditioned by an external framework of controls' (Tonkiss and Passey, 1999, p.258). Indeed many of the factors contributing to micro-politics relate to ethical relations that are beyond the control of official guidance and policies. As a result, micro-politics are not always formally recognised and accounted for and so can be difficult for groups to manage. 
Power is equally difficult to control by outside mechanisms. The exercise of power is apparent when the actions of one person results in another changing their behaviour or action (Foucault, 1982). Lukes describes how one person may exercise power over another by 'influencing, shaping or determining his very wants' (1974, p.23). Hence Latour (1986) argues that it is relations and associations that are powerful rather than an individual or organisation and so power is not given, it is circumstantial. As a result power relations are complex and not automatically equal. In area-based community development powerholders are often made more powerful as the poorer groups remain socially excluded (Shortall and Shucksmith, 2001). Even if a group seeks out individuals that are not involved with existing organisations there is a danger that they then become the empowered, boosting the local elite (Edwards et al, 2001). Equally as Hayward et al argue, 'the choice not to participate can actually be viewed as an act of empowerment' (2004, p.100), although they do acknowledge that it can indicate social exclusion.

Achieving adequate and appropriate involvement, representation and legitimacy is therefore a complex process that is connected to trust and power. Ward and Jones (1999) discuss how the issue of who governs at the local level, tends to be shrouded in ambiguity. More specifically, Skelcher (1998) reveals that structures within local governance in the UK are characterised by non-elected individuals equivalent to nearly three times the number of elected local councillors. In reality groups can be so desperate for membership and involvement that it is easiest to select the usual suspects. This is evident in the membership of many community groups as they contain a core of individuals re-appearing in different guises across the community. The effect is a lack of diversity among community groups in any given area, with grave consequences for the rural development process.

Baum (1999) points out that a lack of diversity can result in those governing a community group implementing projects that diverge from the community which they purport to represent. This will also in turn discourage new membership and ongoing involvement. As with many group features that are considered in the context of micropolitics, membership should not automatically be taken at face value. Just as some are 
involved for very specific reasons, others may not be involved or end their involvement for reasons that go beyond the lack of time to devote effort to an initiative.

This theoretical overview reveals the intricate, sensitive and changing nature of micropolitics. Not revealed by the instantly obvious, they necessitate examination by close scrutiny of interactions resulting from individual positions, motivations, perceptions and characteristics. The group relations and norms that develop are affected by intangibles otherwise categorised as micro-politics. They include power, trust and legitimacy, all of which interrelate to form a dynamic concept. As this article has already indicated, by their very nature micro-politics embody intangible and elusive processes and so identifying and documenting them is a complex and challenging task. For this reason a very particular methodological approach was chosen and in this way the research question determined the methods selected. These issues are described in the following section.

\section{The research: locating micro-politics}

This research was conducted over a three year period by the author while employed by a Housing Association to co-ordinate a rural development and regeneration project, sponsored in the main by two UK Government agencies. The project brief was to work with five different communities in East Anglia promoting sustainable, holistic development. In addition the project sought to demonstrate the contribution of housing associations to this process and to identify successful regeneration practice (McAreavey, 2003). Throughout this paper the five communities are identified as Communities A-E. In each community the author worked closely with a particular regeneration or development group, labelled Groups A-E, corresponding to the relevant Communities AE. All other groups are described within the text.

Several issues are of methodological significance. The research was conducted within an ethnographic framework that places emphasis on Weber's concept of verstehen or meaning (Elwell, 1996). It thus described and sought to understand social action through quality and meaning and so placed emphasis on the process of rural development. 
Secondly, consideration was given to the structures within which rural development practitioners operated recognising the link between structure and agent and the 'duality' of inter-play between policy and practitioners (Giddens, 1984, p.25). The third point of methodological relevance is that the study applied the process of reflexivity. The importance of this approach is evident within rural research (see for instance Newby, 1977, Strathern, 1982, Mayerfield Bell, 1994 and Pini, 2004). It is a theoretical and analytical process that is about more than navel gazing or biographic analysis, it is concerned with critically engaging with those being researched to understand what causes and effects influence their viewpoints (Cook and Crang, 1995). Therefore the findings of this research are not just applicable within the geographic area studied; they have relevance to the broader rural development and regeneration sector.

Cognisant of this framework and of the over-arching methodological ontology that lays emphasis on meaning within social life particular strategies were used. A participant observation approach allowed the study of people in their own setting with close attention to the process of rural development and thereby allowed full scrutiny of micropolitical processes. Such closeness to the practice of rural development was imperative in addressing the research question of the role and significance of micro-politics. The participant observation considered those employed as professionals within the Housing Association and government agencies as well as the individuals who participated in community regeneration within the rural development project. While engaging in this participant observation the balance between the degrees of participation and of observation varied according to the circumstances within the field. For instance, all direct activity within the project placed emphasis on participation. Meanwhile the observation role predominated across the wider study that placed the regeneration project within a broader rural development context. Emerging field relations such as access, acceptance, ethical issues and positionality are closely considered in a separate paper exploring methodology (see Author, forthcoming).

Specific research techniques were used within this model, all of which were crucial in revealing and locating micro-politics. The regeneration project itself was a form of 
action research as it included fact finding, gathering information, participation, taking action and evaluating the action, forming a cyclical process (Lewin, 1973). The action research agenda placed emphasis on the process of creating community action plans along with a final task, informed by the overall process, of publishing a Good Practice Guide (McAreavey, 2003). Findings from the field were revealed and discussed midway through the project with the feedback being used to inform the Good Practice Guide as well as the next phase of the project.

A daily diary that focused on the 'behaviouristic' (Fielding, 1993, p.162) was maintained to record events at the lowest level of interference. This was complemented by an array of documents including field notes, meeting papers, funding and policy papers from the statutory and voluntary sectors, newspapers and interview notes. The latter were drawn from twenty-five semi-structured interviews conducted with professional practitioners and community representatives. Discussion with colleagues, peers and those involved in rural development happened in formal settings such as meetings, seminars and conferences or informal interview sessions. Conversations also occurred in informal situations including conversations prior to and following events and in the more congenial activity of lunch. This complex research strategy allowed for the collection of information from a number of sources and by a range of methods, helping to overcome the indefinable nature of micro-politics and the challenges that follow from this obscurity. Such an approach is vital if the researcher is to get close to the action that is micro-politics.

Data was thus sourced from informants in different ways. Unless otherwise indicated the source of this is coded throughout this article in the following way:-

$\begin{array}{ll}\text { Steering Group member } & \text { SG } \\ \text { Community } & \text { C } \\ \text { Housing Association staff } & \text { H } \\ \text { Other regeneration agency } & \text { A } \\ \text { Documents } & \text { D: followed by }\end{array}$


RJ - Research Journal and personal notes

F - File contents including minutes, official notes of meetings and other project documents

The names of informants have been changed throughout this paper.

\section{Micro-politics at play: research findings}

\section{Group dynamics}

Assuming that the process of rural development ultimately relies on a 'group' working on behalf of its community, its success is dependent on how individuals work together rather than how the 'whole community' comes together. ${ }^{1}$ The group is anything from a number of individuals meeting on an informal basis such as Group C, to a more formally structured partnership responsible for spending a specific budget in a geographic area, as was the case for Group A. Group activity typically relies on a core of individuals. In Community $\mathrm{C}$ on average no more than eight people attended meetings, with normal attendance of about five or six and few apologies. This deviated from turnout at the beginning of the appraisal process when closer to ten individuals attended with another ten sending apologies. As Croft and Beresford (1992) note, this is in contrast with the rhetoric of community development, which is of large scale and broad based involvement. Furthermore Group C met during the day on a monthly basis when making plans for the compilation of a community consultation questionnaire. As activity progressed group members met more regularly, increasing the amount of time given to the project, but also precious weekend time. Not only did a core of individuals under the guise of a 'community group' become the bedrock of the rural development activity, but the meeting become the instrument critical to the group's success.

In these scenarios power tends to lie in the hands of the few who are key players to rural development activities and claim to represent a particular community. The chair of the Group A was also a district councillor, chair of the local housing improvement group and was involved in the local authority tenant liaison group; this all in addition to his full

\footnotetext{
${ }^{1}$ Although the 'whole community' may be invited to attend a larger public meeting, ultimately this is still a representation of that community and the meeting itself is designed by a core group.
} 
time commitment as a teacher in the local school. Other members had multiple functions within the community and they all seemed to know each other from their various roles. The danger was that the group was elitist and exclusive attracting cronies of the chair and discouraging others from getting involved. Some Community A residents revealed that they felt Group A had nothing to do with them and was something that the council had set up (C). Thus the individuals that got involved in turn influenced future group membership - they affected the group’s profile and also others' perception of the group. Ultimately residents a local housing estate did not recognise the legitimacy of the group as furthering the community agenda - they perceived Group A to be another 'council' activity.

On the surface the procedure of holding meetings seems mechanistic and routine - from gathering people together to meeting at suitable times and locations to devising agendas and ensuring meetings are well chaired. While it might appear that procedures within groups are habitual and fixed, analysis of micro-politics reveals another dimension, illustrated by the following quotes:

'Tom just took over our last meeting. You couldn't get a word in edgeways. If he does it again I'm definitely not going back.' (D:RJ)

'We all knew Rick would be voted into the chair, it's hardly a democratic system.' (D:RJ)

'This project has nothing to do with our community, it's Sue's retirement project, not to mention ego-trip.’ (D:RJ)

'There was a real buzz about the place.' (D:RJ)

Such comments characterise micro-politics, revealing their dynamic and intangible features. As a consequence the effectiveness of meetings vary; some groups work well together while others do not. Practical matters are not always clear cut with no guarantee 
of outcome and so the success of groups vary across the regeneration landscape. Ailing groups may have outright spats and disagreements existing in an obvious state of difficulty. Group dynamics were so poor within Group D that a consultant was paid by the Countryside Agency to facilitate a number of public meetings to avoid out-and-out arguments as had happened during some earlier meetings (D:F). Problems can be more subtle than this, happening over a longer period of time and include declining attendance levels, bad mouthing of group activities and individual members and the development of factions. In Community A the village appraisal group went from being a focused group with a concrete task to one which limped gradually out of existence as interest waned and attendance dropped. It never did analyse the results of its community survey.

Conversely, thriving and healthy groups develop meaningful inter-personal relationships and actively enjoy the process of coming together. New friendships emerge or unexpected activities spin out from the group. These groups have a definite 'feel good' factor. A community member of the fledgling Group A acknowledged that even if the bid for funding was not successful they had made progress and achieved great things simply by forming a vibrant regeneration group (D:RJ). While some of this point was a political one made for the benefit of the local authority who was seen by some members of the community to have 'ignored' this geographical area, it was also about the positive intangible aspects of the group. This is the 'glue', or micro-politics, of rural development.

The importance of face-to-face encounters and their associated micro-politics is not always recognised. This may cause them to go unnoticed and unmanaged with potentially damaging effects as a result. Group $\mathrm{C}$ dived into a consultation process that revolved around a completed questionnaire analysing perceived needs and priorities. When the results emerged the Group was not clear about how it would actually achieve any of the changes that people in their community had highlighted as desirable. Not enough time was spent at the outset deliberating on and discussing the process upon which they were about to embark. Meetings consisted of repeating discussions or revisiting decisions made previously and of personal abuses being exchanged between 
particular attendees. People failed to communicate effectively and had various understandings of whose responsibility it was to make the changes identified via the community consultation. Any trust that existed was then eroded as the individuals who had initiated the process were blamed for lack of progress - many group members believed local authorities and other agencies were responsible for undertaking the identified tasks and activities. In turn local authorities and other agencies believed that a joint or partnership approach to potential projects would be adopted. Failure to ascertain clear lines of responsibility, to establish legitimacy and to nurture personal relationships from the outset had damaged the fundamental understanding of the function of the group.

\section{Exploiting micro-politics}

The individuals involved in rural development can engage in tactics to use or abuse their position as they choose. Few interactions occur without a host of other issues lurking in the background. A popular anecdote among local authority officers is that of putting the most important agenda item at the end of a long meeting on the basis that by this stage the councillors will have exhausted discussion on more trivial items and so will consent to the significant issue as they wish the meeting to end (SG). Hence people can manipulate the decisions that are actually made.

The Chair ${ }^{2}$ of Group B, driven by his desire to see a primary care facility in the village, manipulated a public meeting designed to present, discuss and prioritise the results of the village questionnaire. The planning group envisaged this as an opportunity to gain new membership and support for their activities. Stanley chaired the meeting in a very particular way, effectively hijacking and displacing the wider group's agenda and imposing his personal fixation. Consequently it became a mechanism where discontent about the lack of primary health facilities was aired. 'During one of Stanley's rants about the lack of health facilities I caught Joan's eye. For a brief moment there was a flicker of understanding as she rolled her eyes skywards. I assumed she was bored by Stanley's incessant ranting! Not everyone felt the same way as he did and I started to wonder just how much of 'the community' shared his point of view.' (D: RJ)

\footnotetext{
${ }^{2}$ Stanley was the chair of the Rural Development Group (Group B); he also chaired the parish council
} 
Shortly after that meeting the attendance of this woman and her friend became sporadic. At some level these women felt that the objectives of the group were relevant to them, but it was clear that they did not feel that the health issue should have been central to the focus of the group.

Lowry et al (1997, p.186) indicate the importance of questions that are suppressed as well as those that are addressed. So what is not on the agenda for discussion is as important as the matters under debate. In planning the public exhibition and meeting that represented the culmination of the work of Group B, some members suggested inviting officers from various organisations that provided services to the community. The rationale behind this was that these organisations were spending money in the community and as a provider of services they were likely to be interested in learning of the priorities identified by the residents. Moreover opportunities for multi-agency working might be identified and subsequently more efficient use of resources would ensue with better services for Community B as a result. Stanley's pre-occupation with the health agenda continued as he claimed that he did not want the public exhibition diluted with discussion on other, albeit related, issues. Eventually he was persuaded that it might be worthwhile to have other agencies represented. In the event the Primary Care Trust (PCT) was invited and given a seat on stage along with district and county councillors. Other agencies were present but not given such a profile or physical presence. The upshot was that decisions made by the group relating to matters beyond those falling under the remit of the local authorities and the PCT were less likely to be pursued. The Chair had successfully implemented his own agenda through simple tactics.

More sophisticated techniques may be used and Bachrach and Baratz (1962) describe a situation where consciously or unconsciously individuals create barriers to others' raising divergent issues. Consequently obstacles are produced so that one person or party is prevented, by others, from bringing forward contentious matters whose resolution might be unfavourable to those others. Conditions are created where the scope of debate is 
limited to issues with comparatively harmless outcomes to the person or parties influencing the agenda and the group. During the meeting organised by the local authority about whether or not to apply for Single Regeneration Budget (SRB) funding for Community A only certain topics were open for discussion, limiting the scope of that meeting. The option of allocating local authority resources to working on Group A versus an alternative use of these resources was not presented. The matter under debate was whether or not an SRB application should be submitted. A barrier was immediately created impeding individuals who did not agree with this use of local authority resources from raising their viewpoint and so from entering the debate. They appeared to agree with the decision to submit an application for funding to the SRB. These attendees may have remained silent as they lacked the self-esteem to publicise their anxiety about the issue under debate, they would have been uncomfortable about questioning what appeared to be a group consensus. The exclusion of conflict of interest is cited by Lukes (1974) as a hidden dimension of power; consequently he argues that those outside positions of power have not only been omitted from the political process but they have been denied entry. In this example the extent of authority of the regeneration community was limited, with the local authority remaining in control. In addition their power was legitimated by a decision that on the surface appeared to be participatory and evenhanded. In fact they choreographed the very decision that was taken.

\section{Public/private micro-politics}

In reality important decisions such as this are taken away from the public arena. Power is exerted in restricted areas within informal networks where access is limited to social and political elites (Woods, 1998a and 1998b). These backstage spaces are located away from the formal decision making processes, intervention from opponents or the constraints of regulation. The group is powerless as it 'rubber stamps' decisions made by certain individuals rather than the group. The Housing Association leading the regeneration project in this research developed a close relationship with one of the government agencies that went on to fund the project. In so doing it became familiar with that Agency's organisational priorities. When the time came to make a formal submission for funding, the Housing Association was in a position to make a strong case 
and ultimately had a favourable outcome. This alliance was noted by another rural development agency, whose officer felt that had they submitted an application for the same project it would have been unsuccessful (SG). Such alliances have knock-on effects. The group that went on to steer the project was seen by many as one which did not actually possess much power or legitimacy given the networking that had been done away from official and formal procedures. Some partners felt that their involvement was a token attempt by the Housing Association and the funders to be seen to be inclusive (SG).

\section{Legitimacy}

Micro-politics can be employed in a more equitable way with participants trading sources of power based on their perceived legitimacy. Lowndes (1999) suggests that there can be confusion around the source of representatives' legitimacy if the various mandates (election, appointment, common experience, professional expertise, and leadership skills) are not mutually recognised. Representation therefore requires careful consideration of perceived and actual legitimacy as this affects the power and status of the selected representatives.

The capacity in which people become involved in a group affects their perceived legitimacy within that group. One of the community representatives on the Board of Group A represented a large proportion of Community Groups in the area and had a very powerful voice during discussions; this contrasted with the status of an individual from a small Housing Association without housing stock in the immediate area. Unlike the community representative, the other Board member did not have a legitimate profile in the community - as an individual or as a representative of a Housing Association.

However the Housing Association representative had the potential to raise her power in the group. She was employed to co-ordinate a government-sponsored community project and so had access to a network of contacts that existed beyond Community A. Eventually this became advantageous as she was given the semi-formal position of leading the community and neighbourhood strand - one of three within Group A. From 
this point communication with the voluntary sector shifted from being a major obstacle to her involvement to being unproblematic. This change was poignantly demonstrated by an invitation from the Volunteer Centre to brief their network on the emerging bid (D:F).

Croft and Beresford (1992) point out involvement and empowerment is not a zero sum game and so individuals do not have to 'lose out'. Instead it is about altering relationships between participants and creating opportunities for influence. The transformed status of the Housing Association representative was gained in exchange for skills and experience in consulting with communities elsewhere. The local District Council offered her a place on the [small] working group responsible for the development of the SRB project and eventually asked her to lead the group concerned with reaching out to the community. This provided legitimacy in the eyes of Community A which guaranteed a valid position within that community. Playing the empowerment game was important for this individual as it allowed one area of influence to be traded off another ensuring participation in the rural development activity.

\section{Managing micro-politics: discussion}

Maintaining informal relationships and processes alongside more formal ways of working can be vital to the longevity of regeneration partnerships, especially in the face of increasing bureaucracy (Lowndes and Skelcher, 1998). The micro-politics of group relations can be actively managed. Group A Board meetings were prefaced by thirty minutes where sandwiches and coffee were available. This provided an informal opportunity for Board members to meet each other and to discuss issues not necessarily connected to the Group. As a member of this Board, the Author found that the casual tone of the pre-meetings provided a sharp contrast to the, often tedious, formal style of the Board meetings proper. However the down side of running such 'networking' opportunities was that they became the place where pre-meeting decision and agreements were sometimes made. Maintaining positive group relations was crucial for the group but required expending much effort. 
Failure to do this results in fragile group relations and the group eventually falls apart. Lowry et al note the increased use of facilitation services within planning in Hawaii due partly to the fact that 'project controversies are problems based on personality conflicts, miscommunication, and misinformation rather than more fundamental matters of value or principle’ (1987, p.181). Following the completion of its Community Action Plan, Group D had conflicting views about the priority for identified needs and desires. After several fruitless planning meetings, an external consultant was appointed with a specific remit to facilitate a public meeting designed to prioritise action. The facilitator was instantly seen to be objective and not affiliated to any particular faction (although a government agency was in fact paying for his fees). Whereas in the past stand up arguments had been the norm at public meetings, this one contained plenty of discussion but little animosity and, possibly more importantly, was viewed by most individuals concerned as a success. A seemingly ‘objective' person from an organisation outside the community was perceived to be more suitable than the usual suspect who chaired virtually every small group in the community.

In the emerging rural development group, procedures such as ground rules and rules for taking decisions can be scarce. This has serious implications for progress when things are not going well as the group can flounder without clear guidance. Ground rules are designed, not only to minimise conflict within the group, but also to keep these process flowing efficiently. 'Rules of engagement' (Scott, 2004, p.58) may also be used so that partnerships have a common framework within which they operate.

However standardising procedures, such as creating ground rules can be very difficult as it involves formalising intangibles such as trust and friendship. Trust is something that is difficult to produce, it exists organically and as Tonkiss and Passey (1999) point out, formalising trust within organisations can undercut its resources of trust. It can imply a basic lack of trust in the first place and thus draw opposition and hostility as other members feel that their commitment is being questioned. It can devastate trust that freely existed as informal arrangements are replaced with rules and measures which are designed to enforce confidence but can have the converse effect. 
Introducing rules may erode creativity and spontaneity resulting in energy being spent on adherence to seemingly trivial ground rules making the process more arduous than is perceived to be necessary. Groups such as that in Community B resisted adopting formal processes such as setting agendas and keeping minutes. Here group members felt that they were replicating more official (e.g. council) structures by having formalised agendas and minutes. However they eventually found that they needed some record, however brief, of past meetings and activities. This happened because a decision previously made about inviting certain people to the public exhibition was ignored by the Chair, without a record of that decision the group members had little to argue about. Introducing ground rules can be problematic and is not necessarily an indication that things will work out as planned.

Alternatively positive relations may be supported by professionals providing groups with support and direction. Croft and Beresford (1992) note the tension between support and direction. While the enabling and supportive role seems to be consistent with encouraging people's involvement, the organising role can be divisive creating a leader/follower relationship. This is tricky to balance given that the same community will require support and also direction depending on its particular circumstances at any given point in time. In Community $C$ the local champion had a very clear idea of the process that he thought the village appraisal should take. Having had a professional background in community development he was prepared to give this process a generous amount of time. Others also gave up their spare time but soon tired of the endless public meetings, the lack of direction and apparent lack of progress. This resulted in falling attendance and participation, even though the community champion provided abundant support.

In this incident a couple of professionals working with the group attempted to provide direction to the group. They interpreted a particular funder's community involvement guidance notes in such a way that ensured ongoing involvement of the wider group membership. Basically they over-emphasised the need placed by the funder to produce 
results and to share the task of organising events. It meant that the champion had to relinquish some of his power and allow other willing community members to have a greater involvement. The rules of the funder became a tool to influence the champion to consider an agenda beyond his own and to strike a balance between supportive and directive approaches. The professionals' risked alienating the community champion by criticising his chosen method, albeit shrewdly, or to say nothing and watch involvement decline further.

\section{Conclusions}

There is a significant body of theoretical and empirical research on the institutional arrangements and mechanisms for achieving rural development which focuses on broad themes such as governance or gender (see for instance Goodwin, 1998 and Little and Jones, 2000). However academic literature analysing the micro processes of rural development is less abundant.

This article analyses the complex nature of micro-politics showing how group dynamics should not always be taken at face value as they are affected by a number of factors. The analysis began by situating micro-politics within regeneration literature. Micro-politics were identified as nebulous components of group processes and for this reason difficult to theorise and to research. They arise due to groups of individuals interacting and working together on shared activity. Typically difficult to pin down and identify, they are not instantly observable and so close scrutiny of a group is required to identify these processes. Rural development group dynamics such as trust, power, perceptions and personality traits form the components of micro-politics. The result is the emergence of a group with a prevailing positive or negative atmosphere. When a feel-good factor predominates group members enjoy the social aspect of interaction while also progressing to achieve rural development goals. Alternatively relations may be more frayed with group norms consisting of disputes, negative experiences and a general lack of progress. Micro-politics have negative as well as positive impacts and are distinguished from social capital. 
The research presented in this article illustrates how micro-politics are displayed through various mechanisms within a rural development group. They are displayed by individuals engaging in power games founded on trust and legitimacy. Power exists as a result of people acting together. Relations and associations are powerful rather than individuals and so perception and image are important aspects of power. Power tactics are exerted within the meeting norms of decision making and agenda setting. These were found to be complex, encompassing decisions that are made as well as those not made, how decisions are reached, which issues are discussed/which are not and the individuals influencing and controlling the agenda. Consequently the process of decision making and agenda setting can favour one rural development agent over another. By operating behind and beyond the group's agreed meeting format, backstage elites take decisions around potentially contentious or important issues. The less powerful group members feel unable to contest or question their action. Such hidden and subtle dimensions of power reinforce existing barriers, with the less powerful individuals remaining in a weak position.

Nonetheless more positive tactics may be employed when individuals trade their positions in ways that are favourable to both parties. This can be done to achieve legitimacy and power within a group, resulting in benefits such as access to information or networks.

It was stated earlier that micro-politics, by their very nature, are elusive. Once they are identified and their causes are understood, groups can take steps to manage them. Although very simple measures are often required, their successful implementation can be more complicated; they may require additional resources or may be met with opposition. For instance achieving a balance between formal and informal relations helps to ensure that both styles are catered for within meetings. This may entail using two types of meetings rather than a single one to further group objectives, so requiring additional resources. Equally challenging is the task of managing group relations through ground rules that outline group processes, as this can generate suspicion or erode positive components of micro-politics such as trust. While support from external agencies may 
help alleviate poor group relations some group members may believe that such outside advice is not appropriate or necessary. The group's control may also be compromised through alliance with another agency. Furthermore using such measures may also represent the difference between an enjoyable and sociable experience and one which is laden with procedures and regulations.

Successful rural development relies on the positive interaction and dedication of typically small groups of individuals. Moreover people remain involved with initiatives because they enjoy the benefits of social interaction while achieving other specific and common goals. Individuals become disillusioned with rural development because of negative consequences such as personality clashes or abuses of individual power. These elusive social processes, positive and negative, are the micro-politics of rural development. From a policy point of view micro-politics are often an unintended consequence - they are not something that policymakers and funders can readily measure. Rural development rhetoric places less emphasis on micro-politics or group processes than on group objectives and outputs. However the reality is that groups are caught up with these matters and they are a vital part of rural development often making or breaking a process.

In any case the task of managing micro-politics is complex, reflecting their very essence. Accordingly some groups appear to be much more successful than other similar groups for no apparent reason. However, this article offers a theoretical and empirical analysis of micro-politics, highlighting processes which might be used to successfully manage micro-politics. What is clear is that the role micro-politics play in the success of rural regeneration projects needs careful attention. 


\section{References}

Bachrach, P. and Baratz, M. S. (1962) The Two Faces of Power. American Political Science Review Vol. 56 pp. 947-952.

Barnes M. et al. (2003) Constituting 'the public' in public participation. Public Administration Vol. 81.2 pp. 379-399.

Baron S., Field J. and Schuller T. (eds) (2000) Social Capital: Critical Perspectives. Oxford: Oxford University Press pp. 1-38.

Baum, H. S. (1999) Community organisations recruiting community participation: predicaments in planning. Journal of Planning Education and Research Vol.18 pp.187199.

Bloomfield, D. et al. (2001) Deliberation and inclusion: vehicles for increasing trust in UK public governance. Environment and Planning C Vol .19 pp. 501-513.

Body-Gendrot S. and Gittell M. (eds) (2003) Social Capital and Social Citizenship. NY: Lexington Books.

Bridger J.C. and Luloff, A.E. (2001) Building the sustainable community: is social capital the answer? Sociological Inquiry Vol. 71.4 pp. 458-472.

Cheverett, T. (1999) A Research Agenda for Partnerships in Westholm, W., Moseley, M. and Stenlås, N. (eds) Local Partnerships and Rural Development in Europe: A Literature Review of Practice and Theory. Dalarna Research Institute pp.103-128.

Croft, S. and Beresford, P. (1992) The politics of participation Critical Social Policy Issue 35 Vol. 12 no. 2 pp. 20 - 44. 
Department of Environment, Transport and the Regions (1999) Single Regeneration Budget: Round Six Bidding Guidance. London: HMSO.

Dhesi, A. S. (2000) Social Capital and Community Development. Community Development Journal Vol. 35.3 pp. 199-214.

Edwards, B. (1998) Charting the Discourse of Community Action: Perspectives from Practice in Rural Wales. Journal of Rural Studies Vol. 14 No. 1 pp.63-77.

Edwards, B. et al. (2001) Partnerships, power, and scale in rural governance Environment and Planning C: Government and Policy Vol. 19 pp.289-310.

Falk I. And Kilpatrick S. (2000) What is Social Capital? A study of interaction in a rural community. Sociologia Ruralis vol.40 no.1 pp. 87-110.

Foucault, M. (1982) Afterward:The Subject and Power. In Dreyfus, H. L. and Rabinow, P. (1982). Chicagao: The University of Chicago Press pp. 208-226.

Goodwin, M. (2003) Partnership working and rural governance: issues of community involvement and participation. Paper presented to Social Exclusion and Rural Governance Seminar - DEFRA, ESRC and Countryside Agency 28/02/03.

Goodwin, M. (1998) The Governance of Rural Areas: Some Emerging Research Issues and Agendas. Journal of Rural Studies Vol. 14 No. 1 pp.5-12.

Hayward, C., Simpson L. and Wood, L. (2004) Still left out in the cold: Problematising participatory research and development. Sociologia Ruralis Vol. 44.1 pp.95-108.

Latour, B. (1986) The powers of assocation in Power, action and belief: a new sociology of Knowledge Law, J. (ed) London: Routledge. pp.264-280 
Little, J. and Jones, O. (2000) Masculinity, Gender and Rural Policy. Rural Sociology Vol 65. No. 4 pp.621-639.

Lowndes, V. (1999) Management change in local governance in Stoker, G. (ed) The new management of British local governance. Pp. 22-39. London: Macmillan

Lowry, K., Adler, P. and Milner, N. (1997) Participating the public: group process, politics and planning Journal of Planning Education and Research Vol. 16 pp.177-187. Lukes, S. (1974) Power: a radical view. London: Palgrave Macmillan

MacKinnon, D. (2002) Rural governance and local involvement: assessing statecommunity relations in the Scottish Highlands. Journal of Rural Studies Vol. 18 pp.307324.

Maloney, W.A., Smith G. and Stoker G. (2000) Social Capital and Associational Life in Baron S., Field J. and Schuller T. (eds) Social Capital: Critical Perspectives. Oxford: Oxford University Press pp.212-225.

McAreavey, R. (2003) Sustaining Rural Communities. The Countryside Agency.

McDowell, L. (1992) Valid Games? A Response to Erica Schoenberger. Professional Geographer Vol. 44 pp. 212-215.

Murtagh, B. (2001) Partnerships and Area Regeneration Policy in Northern Ireland, Local Economy. Vol.16 No.1, pp.50-62.

Portes A. (1998) Social Capital: Its origins and applications in modern sociology. Annual Review of Sociology Vol. 24 pp. 1-24.

Portes A. (2000) The two meanings of social capital. Sociological Forum, Vol 15 No.1 pp. 1- 12. 
Putnam, R. (1993) The Prosperous Community. The American Prospect Vol. 4 no. 13.

Scott, M. (2004) Building institutional capacity in rural Northern Ireland: the role of partnership governance in the LEADER II programme. Journal of Rural Studies Vol.20 pp.49-59.

Servon, L.J. (2003) Social capital, identity politics, and social change in Body-Gendrot S. and Gittell M. (eds) Social Capital and Social Citizenship. NY: Lexington Books pp.1321.

Shortall, S. (2004) Social or economic goals, civic inclusion or exclusion? An analysis of rural development theory and practise. Sociologia Ruralis Vol. 44 No.1 pp. 109-123.

Shortall S. and Shucksmith M. (2001) Rural Development in Practice: Issues arising in Scotland and Northern Ireland. Community Development Journal Vol. 36 pp.122-133.

Shucksmith, M. (2000) Endogenous Development, social capital and social inclusion: perspectives from LEADER in the UK Sociologia Ruralis Vol. 40 No.1 pp. 72-87.

Skelcher, C. (1998) The appointed state: Quasi-Governmental Organisations and Democracy. Buckingham: Open University Press.

Storey, D. (1999) Issues of Integration, participation and empowerment in Rural Development: The case of LEADER in the Republic of Ireland. Journal of Rural Studies vol. 15. No. 3 pp. 307-315.

Svendsen, G.L.H. and Svendsen, G.T. (2000) Measuring Social Capital: The Danish Cooperative Dairy Movement. Sociologia Ruralis Vol.40 no.1 pp.72-86. 
Taylor, M. (2003) Neighbourhood governance: Holy Grail or poisoned chalice? Local Economy Vol. 18 No. 3 pp. 190-195.

Thompson, N. (2005) Inter-institutional relations in the governance of England's national parks: A governmentality perspective. Journal of Rural Studies 21 323-334.

Tonkiss, F. and Passey, A. (1999) Trust, confidence and voluntary organisations: between values and institutions Sociology Vol. 33 No. 2 pp. 257-274.

Ward, K.G. and Jones, M. (1999) Researching local elites: reflexivity, 'situatedness’ and political-temporal contingency Geoforum Vol. 30 Issue 4 pp.301-312.

Woods, M (1998a) Advocating Rurality? The repositioning of rural Local Government. Journal of Rural Studies Vol. 14 No.1 pp13-26.

Woods, M. (1998b) Rethinking elites: networks, space, and local politics Environment and Planning A Vol. 30 pp.2101-2119

Woods, M. and Goodwin, M. (2003) Applying the rural: governance and policy in rural areas in Cloke, P. (ed) Country Visions. London, Pearson pp. 245-262.

\section{Note}

See Author for forthcoming article exploring methodology, currently under review. 